\title{
Sexual Assault Cases at the Alberta Court of Appeal: THE ROOTS OF E WANCHUK AND THE UNFINISHED REVOLUTION
}

\author{
JANINE BENEDET ${ }^{*}$
}

This article surveys rape law reform efforts in Canadian criminal law by mapping these changes onto the decisions of the Alberta Court of Appeal. First, the article outlines how decisions in the 1970s and 1980s reflected ideas and assumptions about sexual offences. It then traces how these ideas were challenged in law reform efforts in 1983 and 1992. Next the article turns to the definition of non-consent and the Ewanchuk case, and how the reasons at the Court of Appeal reflect evolving attitudes to sexual assault. Finally, the article ends with reflections on sexual assault law following the Ewanchuk decision.

\begin{abstract}
Cet article passe en revue les efforts de réforme des lois sur le viol dans le droit pénal canadien en retraçant ces changements dans les décisions de la Cour d'appel de l'Alberta. D'abord, son auteur évoque la façon dont les arrêts de la Cour d'appel, dans les années 1970 et 1980, témoignaient des idées reçues au sujet des infractions sexuelles. Après quoi, il montre comment ces idées ont été bousculées par les efforts de réforme déployés en 1983 et en 1992. L'auteur se penche ensuite sur la définition de non-consentement et l'affaire Ewanchuk, et sur la façon dont les raisons invoquées dans les décisions de la Cour d'appel rendent compte du changement des attitudes à l'égard des agressions sexuelles. L'auteur conclut son article avec quelques réflexions sur la loi concernant les agressions sexuelles à la suite de l'arrêt rendu dans la cause Ewanchuk.
\end{abstract}

\section{TABLE OF CONTENTS}

I. INTRODUCTION . . . . . . . . . . . . . . . . . . . . . . . . 127

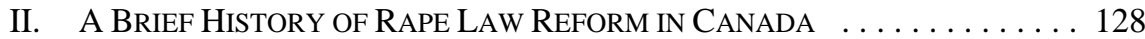

III. DECISIONS OF THE ALBERTA COURT OF APPEAL

in RAPE CASEs PRIOR to EWANCHUK . . . . . . . . . . . . . . . . 131

A. STRANGER VERSUS ACQUAINTANCE RAPE

AND "Blaming THE VictiM” . . . . . . . . . . . . . . . . . . 131

B. ASSESSING HARM AND THE "NON-VIOLENT" RAPE . . . . . . . 133

C. REQUIREMENTS OF RECENT COMPLAINT

AND CORROBORATION ............................ 133

D. EVIDENCE OF SEXUAL HISTORY

AND THE FEAR Of FALSE COMPLAINTS $\ldots \ldots \ldots \ldots \ldots \ldots \ldots$

IV. DeVEloping THE Definitions of Consent AND

NON-CONSENT in SeXuAL OfFENCES . . . . . . . . . . . . . . . . 135

V. THE EWANCHUK DECISION . . . . . . . . . . . . . . . . . . . 138

VI. CONCLUSION ................................ 142

\section{INTRODUCTION}

Few Canadian sexual assault cases are as well-known as $R$. $v$. Ewanchuk. ${ }^{1}$ The Alberta Court of Appeal's split decision upholding the accused's acquittal was unanimously overturned by the Supreme Court of Canada. In the process, it became the leading modern Canadian case on the actus reus and mens rea of sexual assault. The case achieved particular 
notoriety when Justice John W. McClung of the Court of Appeal used the news media to attack Justice L'Heureux-Dubé, ${ }^{2}$ whose concurring reasons at the Supreme Court countered many of the myths and stereotypes evident in Justice McClung's reasons.

The furor triggered by Justice McClung's reasons, however, should not be allowed to obscure the fuller history of the treatment of rape and sexual assault at the Alberta Court of Appeal. The centenary of the Court of Appeal provides a useful opportunity to observe how our understanding of sexual assault law in Canada has shifted in many fundamental ways over the past four decades. Placed in that larger context, the different sets of reasons in Ewanchuk as it moved through the courts can be understood as an important moment of transition in our thinking about sexual assault law.

This article begins with a survey of rape law reform efforts in Canadian criminal law. It then maps these changes onto the decisions of the Alberta Court of Appeal, showing how decisions in the 1970s and 1980s reflected ideas and assumptions about sexual offences that were challenged in the major law reform efforts of 1983 and 1992. The article then turns to the definition of non-consent and the Ewanchuk case, noting that the three sets of reasons at the Court of Appeal reflect the evolving range of attitudes towards this crime of gendered violence. Finally, it ends with some reflections on sexual assault law after Ewanchuk and the importance of recognizing that sexual assault is a crime rooted in sex inequality.

\section{A BRIEF HISTORY OF RAPE LAW REFORM IN CANADA}

The history of sexual assault law in Canada begins with the first Criminal Code of 1892, which codified Canadian criminal law into a single statute, drawing heavily on English common law. ${ }^{3}$ The sexual offences in the original Criminal Code reflect a social understanding of sexual offences that (1) defined sexual offences according to the sexual acts involved rather than according to the harms inflicted on the victim; (2) were written in explicitly gendered terms; and (3) punished many sexual acts per se as immoral without regard to the absence of coercion or the consent of the participants. Rape was defined as carnal knowledge (penetration of the vagina by a penis) without consent, although it contained a marital exception. ${ }^{4}$ The offence was punishable by a maximum penalty of death

2 This included a letter to the editor in which Justice McClung blamed Justice L’Heureux-Dubé for a "graceless slide into personal invective," and then suggested that her reasons might provide a plausible explanation for the disparate rate of male suicide in Quebec: Justice JW McClung, "Right of reply," Editorial, National Post (26 February 1999) A19. This was followed by an interview in which he stated that he did not know that Justice L'Heureux-Dubé's husband has committed suicide, insisting the remarks were meant to be a prod to his "friend Claire" over her "consistent anti-male response on these matters” (Shawn Ohler, “Judge reiterates belief that teen wasn’t assaulted,” National Post (27 February 1999) A1). Justice McClung later issued an apology (John McClung, "Suicide remark was 'included as a facetious chide to the judge,’” National Post (2 March 1999) A8).

3 The Criminal Code, 1892, SC 1892, с 29 [1892 Code]. An account of the development of the law in Canada prior to codification is found in Bruce A MacFarlane, "Historical Development of the Offence of Rape" in The Honourable Mr Justice Josiah Wood \& Richard CC Peck, eds, 100 Years of the Criminal Code in Canada: Essays Commemorating the Centenary of the Canadian Criminal Code (Ottawa: Canadian Bar Association, 1993) 111. 
or life imprisonment. ${ }^{5}$ All other sexual assaults on women 14 years of age and older were prosecuted as the less serious crime of indecent assault. ${ }^{6}$

The 1892 Code also contained offences applicable to male victims and offenders, in particular the crime of "indecent assault on males."7 Anal intercourse was criminal per se, regardless of consent, and was prosecuted under the offence of buggery. ${ }^{8}$ Oral intercourse between persons of any sex came to be prosecuted per se as "gross indecency." 9 The age of capacity to consent to sexual activity was 14 years for girls. ${ }^{10}$ Seduction offences offered some protection to adolescent girls and young women until the age of 16, but only if the prosecution could prove that they were of "previously chaste character" and that the accused was "wholly or chiefly to blame" for the sexual activity. ${ }^{11}$

As in many jurisdictions, the apparent seriousness of sexual offences in the Criminal Code was not matched by any commitment to actually enforcing them. The number of convictions was low and the seriousness of the penalties, particularly for rape, provided justification for evidentiary rules that made acquittals likely. In particular, juries were advised that it was unsafe to convict in the absence of corroboration, that the absence of a recent complaint was indicative of fabrication, and that the past sexual experience of the complaining witness was relevant to undermine her credibility. Few women complained and even fewer offenders were convicted. $^{12}$

This scheme continued largely unchanged until 1968, when the government brought in a package of reforms designed to liberalize access to birth control and abortion and decriminalize consensual homosexual activity between adults over 21 years of age. ${ }^{13}$ These reforms were intended to shift the focus away from particular sexual acts that were labelled immoral or abnormal per se and towards the presence or absence of consent.

These reforms, however, left untouched the core crimes of rape and indecent assault. Convictions for these offences still proved elusive. The definition of non-consent continued to require proof by the prosecution that the complainant had resisted the accused to the extent that she was able. ${ }^{14}$ In addition, without any changes to the restrictive evidentiary rules described above, victims were reluctant to report and be subjected to aspersions on their character and motives. Thus the women's movement continued to campaign throughout the 1970s for feminist-inspired reform of rape laws. ${ }^{15}$

Ibid, s 267. The death penalty for rape was abolished by the time of the 1955 revisions and replaced by a maximum penalty of life imprisonment and whipping: Criminal Code, SC 1953-54, c C-51, s 136 [1955 Code].

1892 Code, supra note 3, s 259(a). The maximum penalty was two years’ imprisonment and whipping. Ibid, s 260.

Ibid, s 174.

1955 Code, supra note 5, s 149.

1892 Code, supra note 3, s 269.

1955 Code, supra note 5, s 138(2)-(3).

See Constance Backhouse, Carnal Crimes: Sexual Assault Law in Canada, 1900-1975 (Toronto: Irwin Law, 2008) for a fuller account of these trends.

Criminal Law Amendment Act, 1968-69, SC 1968-69, c 38, ss 7, 18.

$14 \quad$ See Backhouse, supra note 12 at 290-95; $R$ v Riley (1978), 42 CCC (2d) 437 at 439, 441 (ONCA); $R v$ Hindle, [1978] 2 WWR (2d) 529 at 713-15 (BCCA).

Perhaps the most influential early work was Lorenne MG Clark \& Debra J Lewis, Rape: The Price of Coercive Sexuality (Toronto: The Women's Press, 1977). 
The women's movement was aided in this objective by the passage in 1982 of the Canadian Charter of Rights and Freedoms, which guarantees in section 15(1) the right to legal equality without discrimination based on sex. ${ }^{16}$ There was concern that the existing laws on sexual offences were likely inconsistent with section 15(1) of the Charter, if only because they were drafted in gendered and thus formally unequal terms. ${ }^{17}$ Parliament passed comprehensive amendments to the Criminal Code in 1982, abolishing the offences of rape and indecent assault and replacing them with the gender neutral offence of sexual assault. ${ }^{18}$ This offence uses a definition identical to that used for assault more generally, namely the intentional application of force to another person without their consent. ${ }^{19}$ A sexual assault is distinguished from an assault by being "committed in circumstances of a sexual nature, such that the sexual integrity of the victim is violated." 20 The reference to "force" in the definition of assault refers only to the force inherent in the physical contact and not to any violence beyond that contact. ${ }^{21}$ The reforms also removed the marital rape exemption.

Sexual assault can be prosecuted by indictment, which gives the accused the right to a preliminary hearing and to elect trial by jury, although a trial by judge alone is also available. The maximum penalty is ten years' imprisonment. In cases involving adults, there is no minimum penalty. ${ }^{22}$ Sexual assault can also be prosecuted by summary conviction at the election of the Crown. In such cases, the accused does not have the right to a jury trial or a preliminary inquiry. The maximum penalty is 18 months' imprisonment. ${ }^{23}$

Two additional levels of sexual assault increase in seriousness principally based on the degree of additional violence or injury. Where the accused uses a weapon or causes the victim bodily harm, the maximum penalty increases to 14 years. ${ }^{24}$ Where the assault wounds, maims, disfigures, or endangers the life of the complainant, the accused can be prosecuted for aggravated sexual assault with a maximum penalty of life imprisonment. ${ }^{25}$ However, over time almost all sexual assaults have come to be prosecuted as simple sexual assaults rather than at these elevated levels. ${ }^{26}$

Part I of the Constitution Act, 1982, being Schedule B to the Canada Act 1982 (UK), 1982, c 11 [Charter].

The Supreme Court of Canada later rejected a section 15(1) claim by a man charged with unlawful carnal knowledge of a girl under 14: $R v$ Hess; $R v$ Nguyen, [1990] 2 SCR 906.

An Act to amend the Criminal Code in relation to sexual offenses and other offences against the person and to amend certain other Acts in relation thereto or in consequence thereof, SC 1980-81-82, c 125 [1982 Code Amdendment]. A comprehensive analysis of these reforms is found in Christine LM Boyle, Sexual Assault (Toronto: Carswell, 1984).

Criminal Code, RSC 1985, c C-46, s 265 [1985 Code].

$R v$ Chase, [1987] 2 SCR 293 at 302.

The mens rea of sexual assault is that the application of force be intentional and the offender know that the victim is not consenting. No sexual intent is required. The requirement of knowledge of non-consent is generally assumed in the absence of the accused giving an air of reality to a claim of honest but mistaken belief in consent: Ewanchuk (SCC), supra note 1 at para 23; $R v$ Esau, [1997] 2 SCR 777 at para 14.

Where a firearm is used, the minimum penalty is now five or seven years' imprisonment, depending on whether it is a first or subsequent offence: 1985 Code, supra note 19, s 272(2)(a)(i).

As of 2012, where the victim is under the age of 16 years, there is a minimum of one year of imprisonment where the accused is prosecuted by indictment, or 90 days on summary conviction: ibid, s 271.

Ibid, s 272(2).

Ibid, s 273(2).

Holly Johnson reports that by 2007, 98 percent of police recorded sexual assaults were classified as level 1 (ibid, s 271), up from 88 percent in 1983. See Holly Johnson, "Limits of a Criminal Justice Response: Trends in Police and Court Processing of Sexual Assault” in Elizabeth A Sheehy, ed, Sexual Assault in Canada: Law, Legal Practice and Women's Activism (Ottawa: Univeristy of Ottawa Press, 2012) 613 at 618-19. 
The 1983 reforms to the Criminal Code also made significant changes to the evidentiary rules that had made prosecutions more difficult. The requirement for corroboration was abolished, as was the common law doctrine of recent complaint. ${ }^{27}$ Sexual history evidence was made presumptively inadmissible, subject to three specific exceptions. ${ }^{28}$

Taken as a whole, these reforms were clearly designed to respond to many of the contemporary feminist criticisms of rape law. They did this by giving shape to feminist claims that rape is "violence not sex" and thus casting rape as a species of assault. In addition, making the crimes gender neutral reinforced the idea that sexual assault is a crime that could happen to anyone, of any sex, with the hope that it would be taken more seriously. This shift, however, was in tension with recognizing that the crime of sexual assault both reflects and reinforces sex inequality, a point I return to in more detail below.

It also remained to be seen whether the reforms would have the effect of changing the approach taken by the courts to proof of non-consent, which remained at the core of the offence. The evolution of the legal definition of consent reflects changing understandings of the nature of sexual interactions between men and women, and in particular whether the Crown's onus to prove non-consent means that the complainant is presumed to be consenting unless she makes it plain that she is not. This proved to be a pivotal issue in the cases that followed.

\section{Decisions of THE Alberta COURT OF APPEAL in RAPE Cases Prior to EWANChUK}

Prior to the 1970s, few cases of rape in Alberta ever reached the Court of Appeal. In most of the available cases the allegations involved attacks by strangers, often accompanied by the use of weapons and abduction, or forcible confinement after breaking and entering. Decisions turned on procedural or evidentiary issues rather than the substantive definition of the offence itself. It was not until the 1970s that significant numbers of appellate decisions begin to appear. A review of the decisions of the Alberta Court of Appeal in rape cases from 1970 through the mid-1980s offers examples of the kinds of reasoning that prompted the reform efforts described above and that resurface in Justice McClung's reasons in Ewanchuk. Yet there are also some hints of a more progressive understanding of the harms of sexual offences.

\section{A. STRANGER VERSUS ACQUAINTANCE RAPE AND “BLAMING THE ViCTIM"}

The Alberta Court of Appeal's decisions during this period made clear that rape by a stranger was significantly more serious in law than rape by an acquaintance or date. This was especially so when weapons or additional force were used, or the victim was attacked by a stranger in her own home. This distinction was often reinforced by referring to actions by the complainant that might have contributed to the predicament in which she found herself, or

1985 Code, supra note 19, ss 274-75.

These exceptions, found in section 276(1), were that the evidence was adduced: to rebut prosecution evidence; to establish identity; to support a claim of honest belief in consent. These provisions were found to be unconstitutional limitations on the right to a fair trial in $R v$ Seaboyer; $R v$ Gayme, [1991] 2 SCR 577. 
steps that she might have taken to avoid it. Contributory behaviour by the complainant did not invariably preclude a conviction; the Court of Appeal noted in one case that "[w]hile it may be that she was incautious in accepting a midnight date and going to a hotel room with a much older man, we are all of the view that women are entitled to protection." ${ }^{29}$ The Court of Appeal noted in another case that

\footnotetext{
[i]t is one thing for a woman to go out with a man and have what would otherwise have been a normal social evening turn into a criminal offence. It is another matter for a person to be picked up as a hitch-hiker by a stranger and then to be attacked. In each of those cases, the person attacked at least may think she can take some precautions to see that sort of thing will not happen.
}

In the case of a person who is attacked in her own home, the experience must be a traumatic one. ${ }^{30}$

Contributory behaviour was explicitly used to reduce the offender's sentence on appeal in the 1983 case of $R . v$. Brown, with Chief Justice McGillivray for the Court noting:

\begin{abstract}
[I]t would not have been surprising to that young woman that something might well happen to her going up to the man's apartment between 2 and 3 o'clock in the morning, having been drinking beer all evening, with the expressed intention of smoking marijuana and drinking more beer. That, however, [is] not an answer to his using violence when she rejected his overtures, but we think it is a very different situation from the rapist who breaks into somebody's home and attacks them. ${ }^{31}$
\end{abstract}

In the same year, in $R$. v. Henry, Justice Laycraft stated (in dissent) that while "[r]ape is essentially a crime of violence in whatever circumstance it occurs,” a rape involving breaking and entering or abduction was "an offence grossly aggravated" when compared to "a normal social evening [that] turns into a criminal offence." 32 The justification for this was the ongoing fear that the first category of rapes would promote in the victim. This distinction of course overlooks the fear that victims would feel in every future "normal social evening" following a rape stemming from an ordinary social encounter.

A failure to object or flee sufficiently, however, might then have been fatal to the complainant's credibility, especially where corroboration was lacking. In $R$. $v$. Sitter the accused's conviction was overturned in part because there was no evidence of genital trauma and the complainant did not take the opportunity to flee upstairs to her landlord's family when the accused briefly left the room. ${ }^{33}$ Similarly, in $R$. v. Podetz, the Court of Appeal rejected a Crown appeal from acquittal on the basis that it raised no question of law. In arriving at its conclusion, it was noted that the complainant did not cry out when someone knocked at the door, nor did she take the opportunity to leave the suite earlier when she was

$R v$ Keizer, [1977] AJ No 306 (QL) at para 1 (SC (AD)). Justice Cavanah for the Court also noted that counsel's description of the offence as a "quiet rape" was "unfortunate" (at para 1).

$R v$ McGregor, [1978] AJ No 300 (QL) at paras 20-21 (CA). See also $R v$ Watton, [1979] AJ No 452 (QL) (CA) ("this is not a case where a woman voluntarily accompanies a man who attacks her. At least in that case there may be some element of lack of judgment on the victim's part" at para 4).

(1983), 26 Alta LR (2d) 328 at 328-29 (CA).

(1983), 44 AR 242 at paras 16-17 (CA) Laycraft JA (dissenting in result).

[1979] AJ No 415 (QL) at para 1 (CA). 
in front of the unlocked door. She had also given the accused her photo "with terms of friendship endorsed on it" evidencing her interest in the accused. ${ }^{34}$

\section{B. ASSESSING HARM AND THE “NON-VIOLENT” RAPE}

Earlier appellate decisions also reflected attitudes about which sexual offences were the most harmful. Judges often divided rapes into those that were "violent" and those that were not, with the former category considered to be much more serious. These assessments typically tracked the stranger/acquaintance dichotomy discussed above, even where victims of acquaintance rape were left with injuries. For example in R. v. P.T.M., the victim was raped by her former common-law spouse and the father of her child. ${ }^{35}$ Justice McDermid for the Court reasoned:

The complainant had lived with the appellant for four years, and had a child by him. In a matter of rape there of course is violence, but in this case there was no undue violence. I think it is relevant in considering the length of a sentence to consider the effect on the victim. Here, although the complainant did not consent the effect on her could not be as traumatic as it is on the victim in the usual case of rape. ${ }^{36}$

The effects of sexual abuse on children were often not acknowledged or well understood during this time period. Nonetheless, the Alberta Court of Appeal was prepared to bring a common sense assessment to the question of harm in this context. In $R$. $v$. Dwyer, the Court considered whether to affirm the finding that the offender was a dangerous sexual offender. ${ }^{37}$ Under the predecessor to the current dangerous offender scheme, this finding would warrant sentencing the accused to preventative detention. For such a designation to be issued, it was necessary that the actions of the accused be likely "to cause injury, pain or other evil" to others by the "failure ... to control his sexual impulses." ${ }^{38}$ In this case, the offender had sexually abused a large number of boys. To support its claim that there was no injury caused, the defence relied on the testimony of two psychiatrists who expressed the view that such acts would not cause any enduring problems for the boys, nor any lasting physical or emotional effects. The physicians referred in their evidence to other experts expressing similar views. Justice Clement for the Court rejected this argument, noting that "behavioral psychiatry is still an uncertain field influenced at times by theories which are not necessarily demonstrated when put into practice in the realities of life.”39 The actions of the accused could be said to have caused "evil" to the boys in the opinion of reasonable members of the public. $^{40}$

\section{REQUIREMENTS OF RECENT COMPLAINT AND CORROBORATION}

Many of the appeals of rape convictions during this period are based on the doctrines of recent complaint and corroboration. The common law rule of recent complaint permitted the

(1981), 26 AR 307 at para 15 (CA).

[1977] AJ No 323 (QL) (SC (AD)).

Ibid at para 5.

(1977), 3 AR 96 (SC (AD)) [Dwyer].

Ibid at para 14, citing Criminal Code, RSC 1970, c C-34, s 687 [1970 Code]

Dwyer, ibid at para 20.

Ibid. 
introduction of hearsay evidence that the complainant had reported the rape to someone at the earliest possible opportunity. This evidence was to be used to rebut the natural inference that the failure of a complainant to raise a "hue and cry" meant that her evidence ought not to be believed. ${ }^{41}$

However, evidence of such a complaint could not be used as evidence of the accused's guilt. The rules around recent complaint were complex and technical. They considered whether the complaint was made at the first reasonable opportunity, whether it was spontaneous as opposed to elicited, and whether it specifically referred to "rape" as opposed to being merely "hurt." 42 Trial judges were also required to instruct juries (and to warn themselves) that while they could convict in the absence of corroboration if they were satisfied beyond a reasonable doubt in the truth of the complainant's account, it was unsafe to do so. ${ }^{43}$

\section{EVIDENCE OF SEXUAL HISTORY AND THE FEAR OF FALSE COMPLAINTS}

The first statutory rules applicable to the introduction of evidence of other sexual activity by the complainant were enacted in $1976 .{ }^{44}$ Prior to these provisions, the common law rules of evidence provided that evidence of the reputation of the complainant's unchastity was admissible to undermine her credibility. Evidence of past sexual activity between the accused and the complainant was also relevant to both credibility and consent. For both types of evidence, rebuttal evidence could be called to contradict the complainant's denials of the allegations. The complainant's credibility could also be attacked through cross-examination on specific acts of sexual activity with other partners, but evidence could not be called to rebut her denials of such activity, in accordance with the collateral fact rule. ${ }^{45}$

There is no question that the routine use of sexual history evidence to demean or embarrass the complainant was both commonplace and a deterrent to women reporting sexual assault. In $R$. v. Scovill the complainant herself raised this concern at trial, interrupting the submissions of counsel as to how they would handle the introduction of evidence that she had intercourse with other men earlier in the evening, and prompting the following exchange with the trial judge:

[Witness]: Excuse me.

Your Honour, at the Preliminary Hearing Judge Horrocks stated that they were not allowed to do that type because of some different matters and some law or something like that.

[The Court explained to the witness that the reason for the 1976 amendment was to focus only on what happened that night, as opposed to a long time ago.]

$R v$ Keeler (1977), 4 AR 449 at para 16 (SC (AD)).

$R \vee \operatorname{Timm}(1980), 20$ AR 328 (CA).

$R$ v Kolnberger (1970), 74 WWR 195 at 205 (Alta SC (AD)) citing 1955 Code, supra note 5, s 134.

1970 Code, supra note 38, s 142(1), amended by Criminal Law Amendment Act, 1975, SC 1974-75-76, c 93, s 8.

$R v$ Moulton (1979), 19 AR 286 at paras 40-44 (CA) [Moulton]. 
[Witness:] Would I have to answer questions like who I was with and stuff because it is really none of the lawyer's business or anybody -

The Court: Now you have got an accused person [on] trial for a very, very serious charge. ${ }^{46}$

The 1976 provisions did not have the effect of significantly narrowing the ambit of crossexamination on sexual history. In fact, some judges understood the new rules to have widened the scope of cross-examination by removing the collateral fact bar noted above. Other judges saw the new rules as merely codifying the common law. In R. v. Moulton, the Court of Appeal unanimously agreed that the new provision did not preclude the complainant from being cross-examined on past acts of prostitution, since those would be relevant to her credibility. ${ }^{47}$ The Court seemed to affirm the need for a fishing expedition, noting with approval that the accused would often need to cross-examine the complainant in the in camera hearing because he had "little or no knowledge" of the details of what he was alleging. ${ }^{48}$

The idea that the sexual reputation of the complainant could be used to undermine her credibility was tied to the premise that women frequently made false complaints of rape, and that the motives for such complainants were often impossible to discern, thus making men vulnerable to charges that were easy to make but hard to disprove. Such a disparaging view of women in general, and sexual assault complainants in particular, was made plain in the case law. In R. v. Konkin, the Court of Appeal overturned the accused's conviction on the ground that he had been unfairly prevented from cross-examining the complainant on sexual activity with multiple men on an occasion several months after the alleged rape. ${ }^{49}$ Chief Justice McGillivray for the majority referred with approval to the English authorities, noting that the motive for a false accusation "is frequently indiscernible." 50 The Chief Justice quoted with approval from a 1972 report of the Criminal Law Revision Committee of England, which compared the position of a sexual assault complainant to that of an accomplice:

In sexual cases it is the danger that the complainant may have made a false accusation owing to sexual neurosis, jealousy, fantasy, spite or a girl's refusal to admit that she consented to an act of which she is now ashamed. In the case of an accomplice any special danger that there may be in relying on the witness's evidence is apparent from the fact that he is an accomplice or it can be easily made apparent by the defence. In the case of a sexual offence the danger may be hidden. ${ }^{51}$

\section{DEVELOPING THE DEFINITIONS OF CONSENT AND NON-CONSENT IN SEXUAL OFFENCES}

Few of the Alberta Court of Appeal decisions of the 1970s and 1980s consider the meaning of consent or non-consent in the context of sexual offences. The general rule was that a lack of consent could be expressed by clear verbal and physical resistance, although

[1979] AJ No 397 (QL) (quoting an exchange between the complainant and the trial judge at para 2) (SC (AD)).

Moulton, supra note 45 at para 68.

Ibid at para 5 .

(1981), 31 AR 518 (CA) [Konkin].

Ibid at para 17.

Ibid. 
the complainant need not fight to the point of injury and might submit out of reasonable fear of harm. ${ }^{52}$ While some of the cases turned on a claim of consent by the defendant, most also involved allegations of considerable additional force and coercion which, if true, would eliminate the possibility of consent. The complainant's credibility on the question of nonconsent tended to be attacked collaterally by focusing on corroboration, prompt complaint, and sexual reputation.

Consent or the absence thereof was not defined in the 1982 amendments to the Criminal Code.$^{53}$ However, the reforms did include a section indicating that there was no consent where the complainant "submits or does not resist" because of the application of force, threats, fraud, or the exercise of authority.$^{54}$ It was unclear whether the list of vitiating factors was meant to be exhaustive and whether submission or passivity in situations other than those listed must or could be equated with consent.

Many courts post-1982 continued to instruct the jury to look for emphatic verbal or physical resistance by the victim as evidence of non-consent. Probably the most notorious case during this time period was the 1991 decision from the Supreme Court of British Columbia in R. v. Letendre. ${ }^{55}$ The complainant met the accused in a bar, where they drank and talked over the course of the afternoon. They went back to the complainant's apartment with the intention of going out to eat. Instead, they remained in the apartment and continued to converse. The accused made sexual advances to the complainant who testified that she moved her body so as to thwart his actions and dissuade the removal of her pants. The accused repeatedly told the complainant that he "would not hurt her." ${ }^{\text {"6 }}$ At one point he placed his hands on her neck. Finally the complainant testified that she gave up and let the accused penetrate her. When he finished and went to the bathroom the complainant ran to the apartment of the building superintendent and said that she had been raped.

Justice Hood found that while the complainant may not have wanted the sexual activity to take place, the Crown had failed to prove non-consent in law because the complainant had not clearly and unequivocally rejected the accused's advances. He noted:

The mating practise, if I may call it that, is a less than precise relationship. At times no may mean maybe, or wait awhile, the acts of one of the participants may be easily misinterpreted, a participant may change his or her mind, one way or another part way through it, and co-operation as well as enjoyment may be faked for a number of reasons. In my opinion, in the interests of both participants, it is one which demands clear and unequivocal communication between the parties, particularly if one of them does not want to participate in it. ${ }^{57}$

Protests followed the ruling, focusing in particular on the judge's claim that no could mean something other than no. ${ }^{58}$ The push for further reform resulted in the passage of amendments

$R v$ Asmussen (1983), 45 AR 112 (CA); $R$ v Keizer, [1977] AJ No 306 (QL) (CA).

1982 Code Amendment, supra note 18, s 19.

1985 Code, supra note 19, s 265(3).

(1991), 5 CR (4th) 159 (BC SC) [Letendre].

Ibid at paras $17,19,22-23,26,30$.

Ibid at para 64.

Deborah Wilson, “Judge’s remarks raise storm: 100 protest at law courts” The Globe and Mail (27 April 1991) A4. 
in 1992 which, among other things, gave a statutory definition of consent, defined as the "voluntary agreement of the complainant to engage in the sexual activity in question." 59 A list of five additional factors were defined to amount to a lack of consent: where the complainant is incapable of consenting; where he or she expresses a lack of agreement to engage in the activity or to continue to engage in it; where the agreement is given by a third party; or where the accused induced the complainant to engage in the sexual activity by abusing a position of trust, power, or authority. ${ }^{60}$ This section also indicates explicitly that this list of vitiating factors is not meant to be exhaustive. ${ }^{61}$

While these amendments were an important advance, they did not solve all of the problems associated with the consent inquiry. While the Criminal Code now defined consent, it did not define non-consent, except in the particular enumerated circumstances. Was it legally required that the complainant somehow conveyed the absence of voluntary agreement, or was the prosecution's burden met where it could be shown that there was no expression of voluntary agreement? In other words, was proof of passivity on the part of the complainant consent or non-consent in law? The Supreme Court of Canada first addressed this question in R. v. M. (M.L.), a case from Nova Scotia. ${ }^{62}$ The accused was the teenaged complainant's stepfather. The complainant testified that on several occasions while she was lying in bed, the accused entered her room and touched her sexually. She testified that she had done or said nothing during these events but had simply laid still and pretended to be asleep. The complainant had moved in and out of the home and was in the legal custody of the state, although living with her family, when most of the alleged assaults took place. She later recanted her allegations but then renewed them in court.

The trial judge had found the accused guilty, but the Nova Scotia Supreme Court overturned the conviction and acquitted the accused. ${ }^{63}$ The majority reasoned that, absent some minimal word or gesture of objection, the complainant was to be deemed to have consented. The dissenting judgment rejected the idea that the complainant's passivity could be equated with consent in the circumstances. The defence had not even argued consent at trial. The accused's position was that no sexual contact had occurred. On further appeal to the Supreme Court of Canada, a unanimous Court in a one-paragraph ruling concurred with the dissenting reasons of the court below and restored the conviction. The Supreme Court noted that it was an error to assume that "a victim is required to offer some minimal word or gesture of objection and that lack of resistance must be equated with consent." ${ }^{64}$

M. (M.L.) confirmed that evidence of passivity could amount to proof of non-consent in law. However, it did not settle the question of whether passivity was always non-consent, or whether this depended on other factors, such as the imbalance of power between the parties, or the fact that the victim appeared to be asleep or unconscious. This question was finally 
resolved in 1999 by the Supreme Court of Canada in a case from Alberta, R. v. Ewanchuk, ${ }^{65}$ which became the leading Canadian case on sexual assault.

\section{THE EWANCHUK DECISION}

In Ewanchuk, the complainant was 17 years old and looking for a job. The accused told her that he might have work for her in a shopping mall booth advertising his woodworking business. They sat in his van in the parking lot and then he asked the complainant to go into the attached trailer and view some samples. Once inside, the accused asked the complainant for a massage and began to touch her sexually. Three times the complainant told the accused to stop, and each time he did so, but then recommenced his advances, ceasing only after he had exposed his penis and pressed himself against her. The complainant testified that she tried to project a relaxed and confident demeanour so as not to antagonize the accused. When he finally desisted, he offered the complainant one hundred dollars not to tell anyone.

The trial judge acquitted the accused on the basis that while the complainant had not wanted sexual contact with the accused and was afraid, there was an "implied consent" to sexual activity based on her actions. ${ }^{66}$ She kept her emotional state hidden and did not communicate it to the accused, except on the three occasions when she said "no" and the accused stopped. The Alberta Court of Appeal affirmed the acquittal in a split decision. ${ }^{67}$ There were three separate sets of reasons in the case.

Justice Foisy held, in brief reasons, that the appeal was largely fact-driven and so the conclusions of the trial judge on the question of consent should not be disturbed on appeal. ${ }^{68}$ This was a minimalist judgment that took a narrow view of the scope of appellate review. It declined to engage with the question of whether the legal understanding of consent had moved away from a requirement of demonstrated resistance or objection by the complainant.

Justice McClung took a similar view, referring repeatedly to the failure of the Crown to prove the "criminal intent" of the accused. ${ }^{69}$ He contended that this intent could not be proven where the complainant, by her conduct, implied her consent and the accused was not aware of her true state of mind. He rejected the conclusion that what he was describing should be dealt with under the defence of honest but mistaken belief in consent. He expressed concern that the defence of mistaken belief had been limited by statute to the point where "the evidence of the accused has been judicially devalued."70

Justice McClung explained his conclusions by reference to the complainant's appearance and experience, noting that she "did not present herself to Ewanchuk or enter his trailer in a bonnet and crinolines" and that she had told Ewanchuk that she was living with another couple and was the mother of a baby. ${ }^{71}$ Ewanchuk's actions were characterized as "far less

Ewanchuk (SCC), supra note 1.

Ibid at para 16 [emphasis omitted]. The trial decision is unreported.

Ewanchuk (Alta CA), supra note 1.

Ibid at para 23.

Ibid at para 13.

Ibid at para 9.

Ibid at para 4. 
criminal than hormonal"72 and the complainant's fear of force in the face of his "clumsy passes” was misplaced. ${ }^{73}$ Justice McClung continued, “[i]n a less litigious age going too far in the boyfriend's car was better dealt with on site - a well-chosen expletive, a slap in the face or, if necessary, a well-directed knee."74

These comments clearly echo the conclusions in the earlier cases described above as to victims' so-called contributory behaviour, the relevance of their past sexual experience, and the idea that acquaintance rape is not real rape. It was these comments that were the focus of criticism in the concurring reasons in the Supreme Court of Canada, and also the parts of the decision that sparked the public attention to the case. What is not often noted about this case, however, is that Justice McClung also made a point of criticizing the incorporation into law of the activism of the women's anti-violence movement:

\footnotetext{
It is right that we be constantly reminded that sexual assault can intractably erode the present and future integrity of its victims. Clearly this is so. Yet we must also remain aware that nothing can destroy a life so utterly as an extended term of imprisonment following a precipitately decided sexual assault conviction. In the search for proof of guilt, sloganeering such as “No Means No!”, “Zero Tolerance!”, and “Take back the night!” which, while they marshall desired social ideals, are no safe substitute for the orderly and objective judicial application of Canada’s criminal statutes. ${ }^{75}$
}

This passage is interesting for a number of reasons. It is a thinly-veiled criticism of the dissenting reasons of Chief Justice Fraser as lacking in order and objectivity, influenced instead by unsafe idealism. It clearly echoes the fear of false allegations described above in the Court's earlier cases. Yet on the facts of the case, there was no evidence of a false allegation. The trial judge found the complainant to be a credible witness and her assertions of fear to be genuine. ${ }^{76}$ He simply found that the failure to express that fear more overtly amounted to an implied consent in law. The spectre of the false complaint is therefore substituted with the rush to judgment, egged on by feminist sloganeering.

It is certainly hard to see Ewanchuk as a man “utterly destroyed” by a single sexual assault complaint, to paraphrase the passage above, given his many prior convictions for sexual offences. The first of these, for rape, came in 1970 when he was $21 .{ }^{77}$ He was sentenced to three years' imprisonment. He was convicted of rape again in 1973 and sentenced to ten years' imprisonment. ${ }^{78}$ He continued to commit sexual assaults against both women and children in the years that followed. After finally serving his one-year sentence for this sexual assault of the young woman in his trailer, ${ }^{79}$ he repeatedly sexually assaulted an eight-year-old girl and tried to manipulate her family into not reporting him to police. He was ultimately

Ibid at para 21.

Ibid at para 5.

Ibid at para 21.

Ibid at para 12 .

Ewanchuk (SCC), supra note 1 at para 15.

$R v$ SBE, 2010 ABCA 298, 490 AR 176 at para 4

$R v$ Ewanchuk, [1974] 4 WWR 230 (Alta SC (AD)).

Jill Mahoney, "Ewanchuk sentenced to one year in jail,” The Globe and Mail (20 October 2000), online: $<$ http://www.theglobeandmail.com/incoming/Ewanchuk-sentenced-to-one-year-in-jail/article1192593>. 
sentenced to 16 years' imprisonment for that offence in 2007 and declared a long-term offender. $^{80}$

Chief Justice Fraser dissented, and would have overturned Ewanchuk's acquittal and substituted a conviction. She rejected the existence of a defence of implied consent based on a woman's conduct or lack of resistance. She noted memorably that Canadian law did not consider women to be "walking around ... in a state of constant consent to sexual activity." Focusing specifically on the reasons behind the reforms, she stated that

\footnotetext{
Parliament chose to change the approach to consent from a negative notion to a positive notion of sexual mutuality and agreement and its purpose in doing so ought not to be judicially undermined or ignored. The law has changed and the judiciary cannot continue to be prisoners of the kind of thinking in the past which itself motivated Parliament's legislative amendments. ${ }^{82}$
}

Chief Justice Fraser emphasized that the basis on which the trial judge had acquitted Ewanchuk was not a lack of mens rea. Rather, she stated that the trial judge had erroneously concluded that mistake of fact could not operate to negate mens rea where the accused did not testify. ${ }^{83}$ This was not required; what had changed with respect to mistake of fact in the 1992 reforms was the requirement that the accused take reasonable steps to ascertain that the complainant was consenting.

Instead, the trial judge had held that the complainant's implied consent meant that the Crown had failed to prove non-consent as part of the actus reus, regardless of the evidence as to the complainant's state of mind. According to Chief Justice Fraser, this was a legal error and not a finding of fact, rooted in a failure to understand the way the definition of consent in law had evolved. A complainant's behaviour could only be proof that she consented through conduct where it was her actual or true consent, measured by her state of mind. ${ }^{84}$ These changes in the law recognized that the crime of sexual assault had not been interpreted in a manner consistent with women's equality and sexual autonomy. Chief Justice Fraser explained the legal relationship between non-consent and the accused's knowledge of nonconsent in its social context:

\footnotetext{
Parliament's decision to impose [the reasonable steps requirement as an] evidentiary predicate to an assertion of the defence of mistake of fact was in part in response to the increasing frequency with which that defence was being asserted in sexual assault cases even where no steps had first been taken by an accused to ascertain whether the complainant was consenting. Taken together with Parliament's decision to define “consent” in this context, these amendments represent further legislative steps to overcome the apparent unwillingness by some to let go of the debunked notion that unless a complainant physically resisted or expressed verbal opposition to sexual activity, an accused was entitled to assume that consent existed. ${ }^{85}$
}

"Edmonton sexual predator with 35-year history of sex crimes loses latest appeal,” The Canadian Press (31 March 2010), online: <http://search.proquest.com/docview/346564653?accountid=14474>.. Ewanchuk (Alta CA), supra note 1 at para 67.

Ibid at para 68.

Ibid at para 47.

Ibid at paras 62-63.

Ibid at para 58 . 
On further appeal to the Supreme Court of Canada, the Supreme Court unanimously reversed the decision of the Court of Appeal and entered a conviction. The majority reasons, written by Justice Major, used the case as the occasion to clarify the actus reus and mens rea of sexual assault. Justice Major made clear that the actus reus of sexual assault is proven where the complainant did not, in her own mind, want the sexual activity to take place. ${ }^{86}$ There is no doctrine of implied consent in the context of sexual assault. ${ }^{87}$ While the credibility of the complainant's claims that she did not consent may be measured against her words and actions, there is no legal requirement for resistance or objection. ${ }^{88}$ The determining point is her subjective state of mind at the time of the sexual contact.

As for the mens rea of sexual assault, Justice Major relied on the legal definition of consent in the Code, namely the voluntary agreement of the complainant. For the accused to assert that he believed that the complainant was consenting (and thus lacked the mens rea for the offence) the facts must indicate that he honestly believed that the complainant was communicating her voluntary consent to sex. ${ }^{89}$ Taken together, this makes clear that passivity is not consent. Further, belief that consent was present because of a lack of objection or resistance is a mistake of law and not a mistake of fact negating mens rea. ${ }^{90}$ The legal analysis of Chief Justice Fraser at the Court of Appeal was thus adopted unanimously by the Supreme Court of Canada.

Justice L'Heureux-Dubé wrote concurring reasons in which she agreed with Justice Major's analysis of the law, but noted also that the complainant in this case had in fact objected, by saying “no” and "stop” at least three times. She also criticized at some length Justice McClung's judgment below for his reliance on myths and stereotypes about women and sexual assault. ${ }^{91}$

The Supreme Court of Canada's disposition of Ewanchuk can be understood as an important advance toward an understanding of sexual assault law rooted in sex equality. For the first time, the Court made clear that passivity or a lack of objection could not be equated with consent, and that non-consent was to be measured based on the complainant's own desires. Further, a belief in consent based on a lack of resistance, silence, or any idea of implied consent was a mistake of law and not a mistake of fact negating mens rea. A belief in consent could only be based on a belief that affirmative consent had been communicated.

The judgments at the Alberta Court of Appeal in Ewanchuk reflect the evolution in our legal and cultural understanding of sexual violence. The reasons of Justice McClung endorse

Ibid at paras 45-47.

90 Lucinda Va

91

Ibid at para 31 .

Ibid at para 29.

Ewanchuk (SCC), supra note 1 at paras 26-27.

Ewanchuk(SCC), supra note 1 at paras 88-93. After the public remarks of Justice McClung noted supra note 2, a complaint against Justice McClung was filed before the Canadian Judicial Council asking that he be censured for his remarks. This was followed by a complaint against Justice L’Heureux-Dubé by a conservative women's group alleging that she was biased because of her feminism. The complaint against Justice McClung was upheld; the complaint against Justice L'Heureux-Dubé was dismissed: Kirk Makin, “Judicial council defends judge's 'robust' language in Alberta sexual-assault case,” The Globe and Mail (2 April 1999) A3; Hester Lessard, "Farce or Tragedy?: Judicial Backlash and Justice McClung” (1999) 10:3 Const Forum Const 65. 
the kind of reasoning that animated rape law prior to the 1992 Criminal Code reforms. That is, women make false allegations of rape for no discernible reason, and the only defence for the accused is to attack the complainant's reputation, her contributory behaviour, and her lack of resistance. Moreover, since the accused is not a stranger to the victim (or at least is making no attempt to hide his identity), the harm to the victim can be minimized by treating the assault as a romantic encounter gone awry.

The short reasons of Justice Foisy in Ewanchuk at the Court of Appeal implicitly acknowledge that reliance on "implied consent" was not an error of law. ${ }^{92}$ These reasons do not disparage the complainant, but simply transform her attempt to remain calm and not show fear into a failure to adequately communicate her rejection of the accused's advances. This conclusion is not surprising in a legal environment which for decades prior to the 1992 amendments had assumed that passivity was equivalent to consent in law.

The dissenting reasons of Chief Justice Fraser, however, provide the blueprint for the contemporary law of sexual assault. ${ }^{93}$ She firmly shuts the door left ajar by the equivocal rule in M. (M.L.). ${ }^{94}$ Passivity cannot be consent because women do not walk around in a state of ongoing consent to everyone they meet, available at all times for sexual activity, unless they can persuade us otherwise. ${ }^{95}$ We should presume that people do not want sexual activity until they give some indication to the contrary. This is what an affirmative consent standard means. Consent can be communicated through behaviour as well as words, but evidence of that communication must be clear and unequivocal.

\section{ConCLuSION}

Ewanchuk represents an unfinished revolution in sexual assault law. We continue to see cases, in all jurisdictions, where myths and stereotypes about sexual assault are expressed, or where judges misapply the law, requiring appellate intervention. Two recent cases in Alberta provide examples of this. In $R$. v. Flaviano, a 2013 case, ${ }^{96}$ we see a striking similarity to the facts of Ewanchuk. The trial judge acquitted the accused on a charge of sexual assault against a 17-year-old girl. He was the landlord of her family's residence and came to make repairs while her parents were out. He claimed that the sexual activity was consensual and that she had agreed to it in exchange for money. She testified that she was terrified of his repeated aggressive demands for oral sex and finally acquiesced when he followed her to the basement and warned her that he had a key to her house and knew where her bedroom was. Despite disbelieving the accused's testimony, the trial judge found that the accused may have believed in the complainant's consent because she was "a not very verbal person."97

The Alberta Court of Appeal unanimously allowed the appeal and substituted a conviction. The Court of Appeal noted none of the evidence accepted by the trial judge supported a finding that the complainant communicated her consent to the accused so as to

Ewanchuk (Alta CA), supra note 1 at paras 23-25.

Ibid at paras 26-119.

Supra note 62.

Ewanchuk (Alta CA), supra note 1 at para 60, citing Rosella Cornaviera, "The Reform of Sexual Assault Laws” (1993) 2 Crown's Newsletter 1 at 18-19.

2013 ABCA 219, 553 AR 282 [Flaviano].

Ibid at para 31 [emphasis in original] (citing the trial judge). 
provide a foundation for an honest but mistaken belief. In addition, the question of whether the accused had taken reasonable steps to ascertain consent made no sense, since on his version of events, the complainant had said yes. ${ }^{98}$ The Supreme Court of Canada affirmed this decision in brief reasons. ${ }^{99}$ The inequalities in Flaviano were pronounced: the accused was a much older, large man who was the family's landlord. His defence was that the complainant was not a terrified teenage girl but a scheming prostitute who cried rape.

In $R$. v. Adepoju, the accused struggled with the complainant, who repeatedly made clear her opposition to sexual activity with him. ${ }^{100}$ Finally, after 15 minutes of struggling had failed to dissuade him, and he had forcibly undressed her, the complainant stopped resisting and submitted to the accused to get it over with. The trial judge acquitted, finding that the complainant had stopped saying no, and that her body language had indicated consent. Once again, the Alberta Court of Appeal overturned the acquittal and substituted a conviction. The trial judge had erred in both ignoring all of the sexually assaultive behaviour that took place prior to the sexual intercourse, and in inferring that submission to sexual intercourse was consent. The accused was well aware that the complainant was not consenting; he sent her a text message saying that he had to force her because she would not agree to have sex with him. ${ }^{101}$ Yet the complainant was still found not to be trying hard enough to avoid the sexual assault.

The trial decisions in these cases unfortunately hearken back to the reasoning in Letendre ${ }^{102}$ and the common law definition of non-consent as resistance to the utmost. They serve as reminders that while the substantive law of sexual assault may be clear, it is not always consistently applied. Chief Justice Fraser's dissent in Ewanchuk had revolutionary potential because it moved the law away from the presumption of consent and the requirement of verbal and physical resistance. This shift was embraced unanimously by the Supreme Court in the majority reasons of Justice Major.

At the level of principle, the reasons for this shift have come to be explained in terms of the autonomous liberal individual, who decides when to permit others sexual access to his or her body. Yet while Ewanchuk represents a moment of transition in Canadian sexual assault law - from a standard of consent focused on the complainant's resistance to an affirmative consent standard — there is little doubt that the transition is incomplete. Women who are intoxicated, ${ }^{103}$ teenage girls, ${ }^{104}$ women with mental disabilities, ${ }^{105}$ and abused wives $^{106}$ are among the women who have found it difficult to have their lack of consent to

$98 \quad$ Ibid at paras 38-39.

$99 \quad R v$ Flaviano, 2014 SCC 14, [2014] 1 SCR 270.

$100 \quad 2014$ ABCA 100, 569 AR 399.

$101 \quad$ Ibid at para 3.

102 Supra note 55.

103 Janine Benedet, “The Sexual Assault of Intoxicated Women” (2010) 22:2 CJWL 435.

104 Janine Benedet, “The Age of Innocence: A Cautious Defense of Raising the Age of Consent in Canadian Sexual Assault Law” (2010) 13:4 New Criminal Law Review 665.

105 Janine Benedet \& Isabel Grant, “A Situational Approach to Incapacity and Mental Disability in Sexual Assault Law” (2011-2012) 43:1 Ottawa L Rev 1.

106 In 2011, in $R \vee J A, 2011$ SCC 28, [2011] 2 SCR 440, the Court overturned a decision of the Ontario Court of Appeal which found that the Crown had failed to prove that the complainant had not given advance consent to sexual acts that occurred after she was choked into unconsciousness by her spouse. The Supreme Court's reasoning matched the approach of the majority of the Alberta Court of Appeal in $R v$ Ashlee, 2006 ABCA 244, 391 AR 62 [Ashlee] which found that consent and capacity to consent must be contemporaneous with the sexual activity, and that the law did not recognize the concept of 
sexual activity recognized in law, because they do not always fit the idealized model of the individual liberal subject who grants and withholds sexual access in a way that mirrors her subjective state of mind.

What is overlooked in this formulation of the autonomous consenting subject is the explanation Chief Justice Fraser offered for the move to an affirmative consent standard: that the 1992 legislative reforms were explicitly a project about sexual assault as a practice of sex inequality. It is this second aspect of the Ewanchuk dissent at the Alberta Court of Appeal - the understanding that sexual assault is a gendered crime of violence - that explains why it is wrong to rely on the accused's belief as to whether the complainant objected enough to overcome her implied consent (a consent that could be implied simply by virtue of her being female and in his line of sight). According to Chief Justice Fraser, the affirmative consent standard and the reasonable steps provision were intended to be sex equality laws.

This aspect of Chief Justice Fraser's decision was endorsed in Justice L'Heureux-Dubé's concurring reasons at the Supreme Court of Canada, but it does not find its way clearly into Justice Major's majority reasons. The temptation for legal scholars is to read the two Supreme Court judgments together as if they were a single judgment — the majority's exercise in statutory interpretation and the concurrence's disavowal of sexism - but subsequent cases have shown that the Supreme Court seems more comfortable relying primarily on Justice Major's reasoning. ${ }^{107}$ Recognition of the connection between sexual assault and sex inequality at times has proven elusive. Yet keeping the focus on inequality and the gendered nature of sexual assault offers the most promise for avoiding the mistakes of the past.

advance consent to sex. The approach in Ashlee, in my view, was the only approach consistent with sex equality.

107 The Supreme Court's most recent substantive sexual assault decisions are mostly treated as exercises in statutory interpretation, expressed in gender-neutral terms and without reference to the equalityseeking objectives of the legislative reforms: see e.g. $R v$ JA, supra note 106; $R v$ Hutchinson, 2014 SCC 19, [2014] 1 SCR 346. 